\title{
IN VIVO MULTISTEP MUTAGENESIS INDUCTION USING COLCHICINE ON COWPEA MUTANT 1 (Vigna unguiculata L. Walp)
}

\author{
I Gede Ketut Susrama* and I Gede Putu Wirawan
}

\author{
Department of Agroecotechnology, Faculty of Agriculture, Udayana University \\ *Corresponding author: ketutsusrama@unud.ac.id
}

\begin{abstract}
In the previous research, we obtained three catagories of M1 mutant cowpea namely 1) purple pod mutant cowpea, 2) green pod mutant cowpea which has three pods in a stalk, and 3) green pod mutant cowpea which has two pods in a stalk. All those three catagories of M1 mutant cowpeas were treated again with colchicine in a multistep mutagenesis proses in vivo. Then, we found changes in number of leaflet in a petiole to 4 leaflets (quadrifoliate) and to five leaflets in a petiole (pentafoliate). These changes are indications that beside as a chromosome multipying alkaloid, colchicine causes other genetic changes as well. Through this mutagenesis research, we created gigas mutant cowpea that having longer leaves, longer pods and heavier seeds. The accurrence of two kinds of insect pests attack were found namely cowpea aphid Aphis craccivora and pod sucking bug Riptortus linearis.
\end{abstract}

Keywords: colchicine, pentafoliate, gigas cowpea, and cowpea aphid Aphis craccivora

\section{INTRODUCTION}

Cowpea is a kind of beans that suitable for tropical climate and it grow well even in semi-arid regions (Timko and Singh, 2008). This pea is also grown well on a wide variety of soils and soil conditions, however grown best on well-drained sandy loam soils or sandy soils, where soil $\mathrm{pH}$ is about 5.5 to 6.5 (Pandey, 2010). A pod containing a number of seeds which varies depend on pod length usually between eight to twenty seeds. Seed length varies between $2-12 \mathrm{~mm}$ and the weight of 100 seeds is between 5-30gram (Anon, 2014). Dry pod ready for harvesting in two and half months approximately on day 65 to day 75 (Agbogidi and Egho, 2012).
Various efforts in improving crop quality have been done so far and producing three catagories of crops i.e. hybrid crops, mutant crops and transgenic crops. Hybrid crops are produced by performing various forms of hybridization such as interbreeding between individuals, interspesifically and intraspesifically. Mutant crops are produced from mutagen treatment whether using chemical mutagen and or physical mutagen. Transgenic crops are through the applications of genetic engineering techniques. Those three ways of achieving new varieties having their own advantages and disadvantages.

Mutation can actually occur naturally in nature due to continous exposure by ultra 
violet rays from sunlight called spontaneous mutations or natural mutations. For human being, spontaneous mutation could be harmful, neutral or beneficial. The frequency of natural mutation is low or undetectable therefore to take advantage of plant mutation phenomenon, induction is necessary in increasing mutation frequency. In this matter, it means that human intervention needed to increase the frequency of mutation by utilizing mutagen either in the form of chemicals or physical substance.

In our previous research entitled "Crop improvement through induced mutagenesis in vivo using colchicine on cowpea (Vigna unguiculata L. Walp)", we obtained cowpea mutant 1 in three categories i.e. 1) purple pod cowpea mutant, 2) cowpea mutant with green pod having 3 pods in a stalk, and 3) cowpea mutant with green pod having 2 pods in a stalk similar with common variety (Susrama and Wirawan, 2017). Those three categories of mutant cowpea were treated again with colchicine in a multistep process of mutagenesis in vivo. Long term's general objectives of this research are intented to 1) creating higher quality crops, 2) increasing crop productivity and its economic value, and 3) contributing to world effort in improving crop quality. Short term specific objectives is to improve the quality of cowpea i.e. to produce 1) Higher resistance cowpea to a certain plant pests and diseases, 2) longer pods, and 3) pithy seed.

\section{MATERIALS AND METHODS}

Cowpea mutant 1 harvested from previous seeds were visually selected of which healthy seeds that uniform in size and color and having no pest attack symptom. In $3 \%$ hydrogen peroxide, $0.1 \%$ colchicine solution was made and then diluted to $0.01 \%$ with the same solvent and subsequently used for treatment on all three kind of our cowpea mutant 1 i.e. purple pod cowpea mutant, cowpea mutant 1 having 3 pod per stalk, and cowpea mutant 1 having 2 pod per stalk. Twenty five seeds were soaked per category in a petridish for 24 hours, drain on dry tissue paper and then grown in a prepared land.

\section{RESULTS AND DISCUSSION}

\section{Purple pod mutant cowpea}

Our purple pod mutant cowpea seed grown into different variety which having smaller leaf size. Mutant cowpeas that were grown from purple pod mutant cowpea having leaf size $(6,5 \pm 0,59 \mathrm{~cm})$ smaller than green pod mutant cowpea $(10,6 \pm 1,84 \mathrm{~cm})$ i.e. $39 \%$ smaller. However, all purple pod mutant cowpeas were attacked with cowpea mosaic virus (CPMV) and failed to produce pod, whereas green pod mutant cowpea, with two or three pods per stalk weren't attacked with CPMV and succesfully produced pods. This an indication that the green pod mutant 
cowpea having higher resistance comparing to purple pod mutant cowpea.

\section{Number of leaflet on a petiole}

As like other beans, cowpea has 3 leaves at each petiole. In mutant cowpea resulted in multistep colchicine treatment, we found changed in number of leaflet into four leaflet on a petiole (quadrifoliate) and changed into five leaflet on a petiole (pentafoliate). This phenotype changes reinforce the indication that at the time genome doubling due to colchicine treatment, when every gene doubling was conducted, many kind of changes could be happened on the number and configuration of nitrogen base in every DNA of a gene. Data of leaf size changes due to mutagen treatment sometimes are doughtful considering the possibility of growth rate and leaf size variations of crop. Normally the number of leaf blade at a petiole in a bean crop is three leaves. Its change into four leaves or five leaves are a phenotypic change that is undoubtedly a change induced by the mutagen treated in this research that is colchicine. Based on our knowledge, environmental influences such as sunlight, moisture, soil condition, and others have never been published causing such phenotypical changes. Those phenotypic changes indicated that there were has been genotypic changes as well. Previously, Gnanamurthy and Danavel, 2014 have found changes in the number of leaflet per leaf of mutant cowpea changed into four leaflet (quadrifoliate) at a petiole due to seed treatment with EMS (Ethyl Methane Sulphonate) $25 \mathrm{mM}$ and the mutant was called cowpea leaf mutant. In this research, in addition to quadrifoliate (Fig. 1, center) we found that multistep colchicine treatment could lead to the formation of pentafoliate, five leaflet on a petiole (Fig. 1, right).
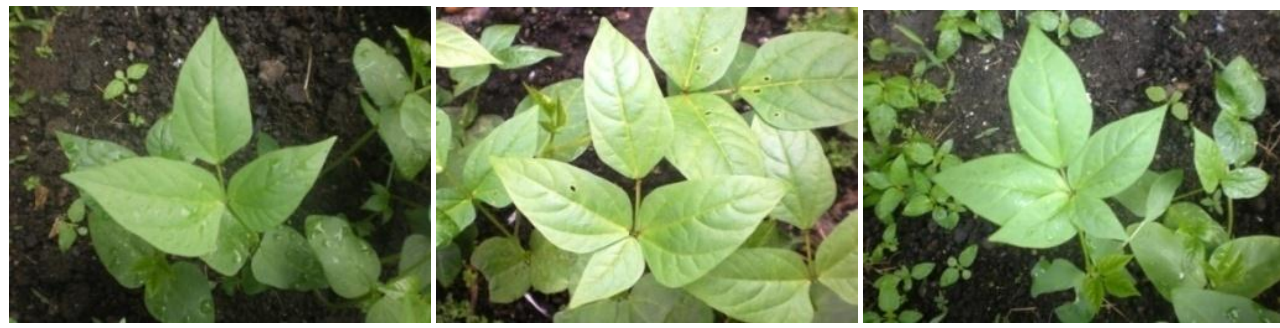

Fig. 1. Trifoliate (left), quadrifoliate (center) and pentafoliate (right)

\section{Change of leaf length}

Through multistep in vivo colchicine treatment on seed we succesfully created gigas mutant cowpea that having longer leaf (jumbo leaf). The leaf length of gigas mutant cowpea from this research reachs $14 \mathrm{~cm}$.
Average leaf length of green pod cowpea was between $10,6 \pm 1,84 \mathrm{~cm}$ to $11,0 \pm 2,08 \mathrm{~cm}$. Gigas mutant cowpea is a phenotypical change that is eagerly awaited in a mutagenesis induction research using colchicine considering the ability of colchicine to multiply the number of 
plant chromosome (polyploidizing agent). Gigas variety was expected in M1 generation of this research however the expected trait didn't appear. Ayayi et al., 2014 reported that in M1 generation, colchicine treatment is used to reduced most of the morphological characters of treated crop. Fortunately, gigas trait then appeared in M2 generation. Anyway, genome doubling of an organism as a whole is still a challenge (Yant and Bomblies, 2015), in this matter including attemps to duplicate plant genome to create polyploid plants. Applying multistep treatment to induce mutagenesis with colchicine or perhaps other mutagens seems promising in developing larger plant size.

\section{Pod and seed of gigas mutant cowpea}

Mutant gigas cowpea pods were harvested from mutant cowpea individuals that having jumbo leaves. The pods of gigas mutant cowpea was reached $18 \mathrm{~cm}$ in length with mean and standard deviation of $13.3 \pm 3.11 \mathrm{~cm}$. The green pod length of three pods per stalk (Green pod 1) and two pods per stalk (Green pod 2) in average were $11.7 \pm 1.73 \mathrm{~cm}$ and $11.8 \pm 1.98 \mathrm{~cm}$ respectivelly (Fig. 2). The weight of 100 mutant seeds from green pod cowpea having two pods per stalk was in average $13.30 \pm 3.11$ gram and the weight of 100 mutant seeds from green pod cowpea having three pods per stalk was in average $13.50 \pm 0.60$ gram. Gigas mutant cowpea seeds weight was everage
$15.60 \pm 0.47$ gram or $16 \%$ heavier compare to two categories mention above. This result is in accordance with Ayayi et al., 2017 which mention that colchicine treatment improving some traits of cowpea such as increase cowpea seed weight. Those gigas mutant cowpea seeds will be planted in further research to determine whether its gigas nature is inherited.

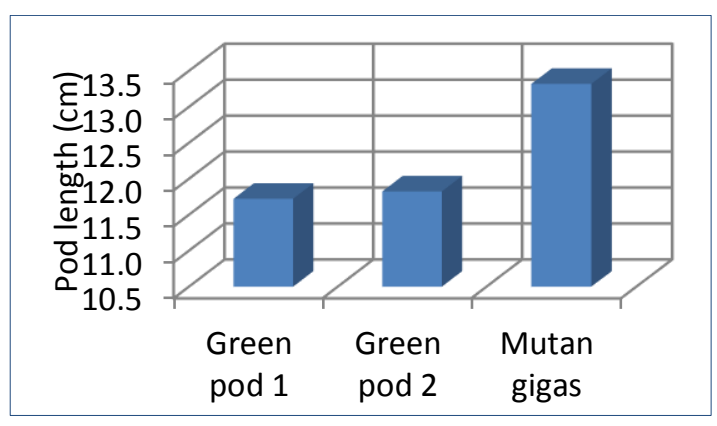

Fig. 2. Pod length of green pod 1, green pod 2 and gigas mutant cowpea

\section{Attack of cowpea aphid and pod sucking pest}

Cowpea aphids Aphis craccivora (Fig. 3, left) starting attacked at 73days after planting (DAP) on cowpea crops that grown from seeds of mutant 1 having 3 pod per stalk and also those grown from seeds of mutant 1 having 2 pod per stalk. Pod sucking bugs Riptortus linearis (Fig. 3, right) were attacked at 145DAP on both catagories mention above. Based on just the visual observation in this research we could not draw any conclusion yet whether there any resistance difference or tolerance trait of cowpea crops that we observed against those two insect pests. 

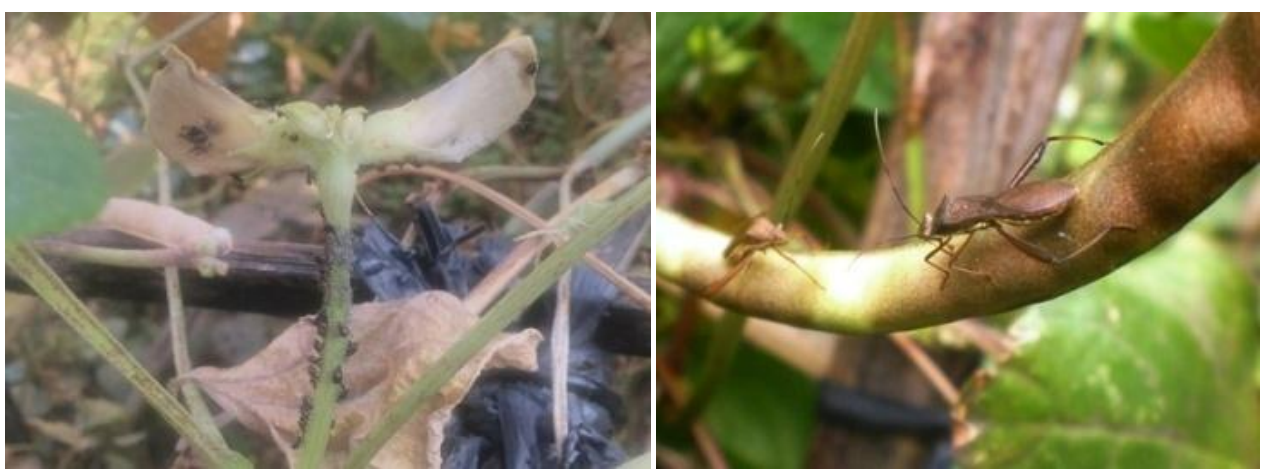

Fig. 3. Aphid attack on cowpea flower (left) and pod sucking bug on pod (right)

Cowpea aphid attacks occurred first on cowpea shoots, then on flowers and finally on pods. To ensure the harvest, we apply chemical control measures with insecticide with consideration that 1) aphid proliferation is very quick, and 2) aphid does not just cause direct damage on a crop however also act as a virus disease vector especially cowpea mosaic virus. Pod sucking bug Riptortus linearis is a very common pest attacking beans include cowpea at the time a bean crop started forming a pod. Both young and mature pods were attacked.

\section{ACKNOWLEDGEMENTS}

Authors would like to express our highly appreciation to the Higher Education Department of Indonesian Government that through Udayana University Research and Community Extension that has provided a PNBP (HPUU) fund for supporting this research. We also thanks to all colleagues, students of Agroecotechnology department and my family members who in some ways have involved in this research.

\section{REFERENCES}

Agbogidi, O. M., \& Egho, E. O. (2012). Evaluation of eight varities of cowpea (Vigna unguiculata (L.) Walp. In Asabo Agroecological Environment, Delta State, Nigeria. European J. Sustain. Development, 1(2), 303-314.

Anonymous. (2014). Production guidelines for cowpea. Directorate of Plant Production, Agriculture, Forestry and Fisheries department, Republic of South Africa. Pretoria.

Ayayi, T. A., Ologundudu, A. F., Azuh, V. O., Daramola O.F. and A.R. Kajogbola. (2017). Induced-Colchicine genetic variations in M2 and M3 generations of cowpea (Vigna unguiculata L. Walp.). Jordan J. Agric. Sci, 13(2), 293-304.

Ayayi, T. A., Akinlolu, O. O., Oluwatoyin S. O., \& Opeyemi, C. O. (2014). Influence of colchicine treatments on character expression and yield traits in cowpea (Vigna unguiculata L. Walp). Global J. Sci. Frontier Res, 14(5), 15-20.

Gnanamurthy, S., \& Danavel, D. (2014). Effect of EMS on induced morphological mutants and chromosomal variation in cowpea (Vigna unguiculata (L.) Walf). Intern. letters of nat. Sci, 22, 33-43. 
Pandey, B. S. (2010). Induced mutagenesis in cowpea (Vigna unguiculata L. Walp.). Thesis. Anand Agricultural University. Gujarat.

Susrama, I. K. G., \& Wirawan, I. G. P. (2017). Crop improvement through inducing mutagenesis in vivo using colchicine on cowpea (Vigna unguiculata L. Walp). Intern. J. of Biosci. Biotech, 4(2), 85-91.

Timko, M. P., \& Singh, B. B. (2008). Cowpea, A multifunctional legume in genomics of tropical crop plants chapter 10, P.H. Moore, R. Ming (eds.). Springer.

Yant, L., \& Bomblies, K. (2015). Genome management and mismanagement-cell-level opportunities and challenges of whole-genome duplication (Review). Genes \& Development, 29, 2405-2419. Cold Spring Laboratory Press. 